\title{
ZONASI INTRUSI AIR ASIN DENGAN KUALITAS FISIK AIR TANAH DI KOTA SEMARANG
}

\author{
ZONING SALT WATER INTRUSION WITH PHYSICAL GROUNDWATER QUALITY IN \\ SEMARANG CITY
}

\author{
Dino GunawanPryambodo ${ }^{1)}$, Joko Prihantono( ${ }^{1)}$ dan Supriyadi $^{2)}$ \\ ${ }^{1)}$ Pusat Penelitian dan Pengembangan Sumberdaya Laut dan Pesisir \\ Balitbang KP, KKPJl. Pasir putih 1, Ancol Timur Jakarta 14430, \\ Telp: (021) 64713850 \\ e-mail : dinogunawan77@gmail.com \\ 2)Jurusan Fisika FMIPA Universitas Negeri Semarang
}

Diterima tanggal: 3 Oktober 2016, diterima setelah perbaikan: 25 Januari 2017, disetujui tanggal: 26 Januari 2017

\begin{abstract}
ABSTRAK
Air tanah sering digunakan sebagai sumberdaya air untuk keperluan air bersih dan air minum. Kebutuhan air tanah di kota-kota besar seperti kota Semarang terus meningkat seiring dengan bertambahnya jumlah penduduk. Meningkatnya jumlah penggunaan air tanah di wilayah pesisir Kota Semarang mengakibatkan terjadinya intrusi air asin yaitu masuknya air laut kedalam air tanah. Tujuan penelitian ini adalah untuk membuat peta zonasi penyebaran intrusi air asin di wilayah kota Semarang. Sebaran intrusi air asin dilakukan dengan menguji kualitas air tanah secara langsung (insitu) dengan alat multi-parameter water quality meters WQC 24 TOA DKK. Nilai yang diuji antara lain $\mathrm{pH}$, salinitas dan dayahantar listrik (DHL). Hasil penelitian menunjukkan nilai pH didaerah penelitian sebagian besar berada diatas 7,5 dalam hal ini bersifat basa yang masuk dalam batasan air payau. Nilai Salinitasnya bernilai diatas $0,5 \%$ hal ini sudah masuk dalam katagori air payau. Nilai Daya Hantar Listrik (DHL) air tanahnya diatas $900 \mu \mathrm{mhos} / \mathrm{cm}$ yang mengakibatkan berubahnya fungsi air tanah menjadi air payau. Ketiga peta sebaran nilai kualitas air tanah (pH, Salinitas, DHL) tersebut disajikan dengan peta zonasi untuk mengetahui pola sebaran intrusi air asin di wilayah kota Semarang. Peta zonasi di buat menjadi tiga zona yaitu zona air tawar, zona air payau, zona air asin, sebagian besar wilayah kota semarang fungsi air tanahnya sudah berubah menjadi air payau, untuk zona air tawar terdapat di wilayah semarang selatan.
\end{abstract}

Katakunci : Intrusi air asin, Air tanah, Kualitas air, Kota Semarang

\begin{abstract}
Groundwater is often used as a resource of water for clean water and drinking water. Needs groundwater in major cities such as Semarang continues to increase along with the increase in the population. Increasing the amount of use of groundwater in coastal areas of Semarang result in saltwater intrusion i.e. sea water intrusion into groundwater. The purpose of this research is to create a zoning map the spread of saltwater intrusion in the city of Semarang. Distribution of saltwater intrusion is done by testing the quality of the groundwater directly (in situ) by equipment of multi-parameter water quality meters DKK TOA WQC 24. Values tested include pH, salinity and electrical conductivity (EC). The results showed a pH value of most of the research area is above 7,5 that in this case alkaline in the category brackish water. Values above $0.5 \%$ salinity worth it is already included in the category of brackish water. Rated Electrical Conductivity (EC) groundwater above $900 \mu$ mhos $/ \mathrm{cm}$ which result in changes in the function of groundwater into the brackish water. The third distribution maps of groundwater quality values ( $\mathrm{pH}$, salinity, $\mathrm{DHL}$ ) are presented in the zoning maps to determine the pattern of distribution of salt water intrusion in the city of Semarang. The zoning map was made into three zones: fresh water zone, brackish water zone, zones saltwater zone, most areas are already groundwater functioning Semarang city has turned into a brackish water. The fresh water zone are in the area south of Semarang.
\end{abstract}

Keywords: salt water intrusion, Groundwater, Water Quality, Semarang city

Zonasi Intrusi Air Asin Dengan Kualitas Fisik Airtanah Di Kota Semarang - Dino GunawanPryambodo, Joko Prihantono dan Supriyadi 


\section{PENDAHULUAN}

Kota Semarang merupakan ibu kota dari Propinsi Jawa Tengah dan juga merupakan kota metropolis terbesar nomor lima di Indonesia (Kompasiana, 2016)yang berada di pesisir utara pulau jawa dengan jumlah penduduk lebih dari 1,7 juta jiwa (dispendukcapil.semarangkota.go.id,2016).

Dengan perkembangan yang sangat pesat akan mengakibatkan meningkatnya kebutuhan air bersih untuk berbagai keperluan, kebutuhan air yang semakin meningkat akan memacu aktivitas eksploitasi sumberdaya air tanah di kota semarang untuk menunjang kegiatan perekonomian yang semakin meningkat. Air bersih di kota Semarang diperlukan untuk menunjang kebutuhan sektor domestik (penduduk dan fasilitas umum), sektor industri, dan sektor pariwisata (hotel). Mengingat kota Semarang sebagai kota metropolitan, maka kebutuhan air bersih penduduk adalah 150 lt/orang/hari (Kimpraswil.2003), Untuk memenuhi dari ketiga kebutuhan tersebut diatas maka air bersih di penuhi oleh pihak PDAM kota Semarang sebesar $56,1 \%$ sedangkan sisanya diambil dari diambil dari air tanah, pada tahun 2010 ketersediaan air tanah mencapai 4,04 juta $\mathrm{m}^{3}$ (Susanto, 2010).

Air bawah tanah atau air tanah merupakan sumber air tawar terbesar di planet bumi, mencakup 24\% dari total air tawar atau 10,5 juta $\mathrm{km}^{3}$ (Winanti, 2008). Seiring dengan banyaknya aktivitas manusia yang banyak memerlukan air tanah maka pemanfaatan air tanah meningkat dengan cepat, di beberapa tempat tingkat ekploitasinya sudah sampai tingkat yang membahayakan.

Terjadinya pengambilan air tanah yang terus menerus tanpa memperhitungkan daya produksi dari suatu akifer maka dapat menimbulkan terjadinya intrusi air asin terhadap sumber air bawah tanah yang berasal dari air laut (Kodoatie, 1996). Kondisi geologi kota Semarang bagian utara yang berupa endapan alluvial yang berupa lensa-lensa pasir (Marsudi, 2000).Dengan keadaan geologi seperti tersebut maka keasinan air tanah tidak selalu merupakan akibat dari intrusi air laut. Pada beberapa kejadian keasinan air tanah bisa terjadi karena air laut yang terjebak di dalam sedimen pada saat proses sedimentasi (connate water) (Todd, 1980).

Penelitian ini bertujuan untuk menyusun peta zonasi air tanah asin yang dihasilkan dari pengukuran sifat fisik kualitas air tanah di kota Semarang. Dari peta zonasi tersebut akan diketahui sejauh mana intrusi air asin masuk kedaratan kota Semarang sehingga dapat dilakukan cara pencegahannya.

\section{BAHAN DAN METODE}

Penelitian dilakukan di kota Semarang provinsi Jawa Tengah dengan mengukur sampel air tanah (sumur pompa penduduk) sebanyak 40 titik sampel (Gambar1) yang dilakukan dari tanggal 30 Agustus 2016 - 1 September 2016.

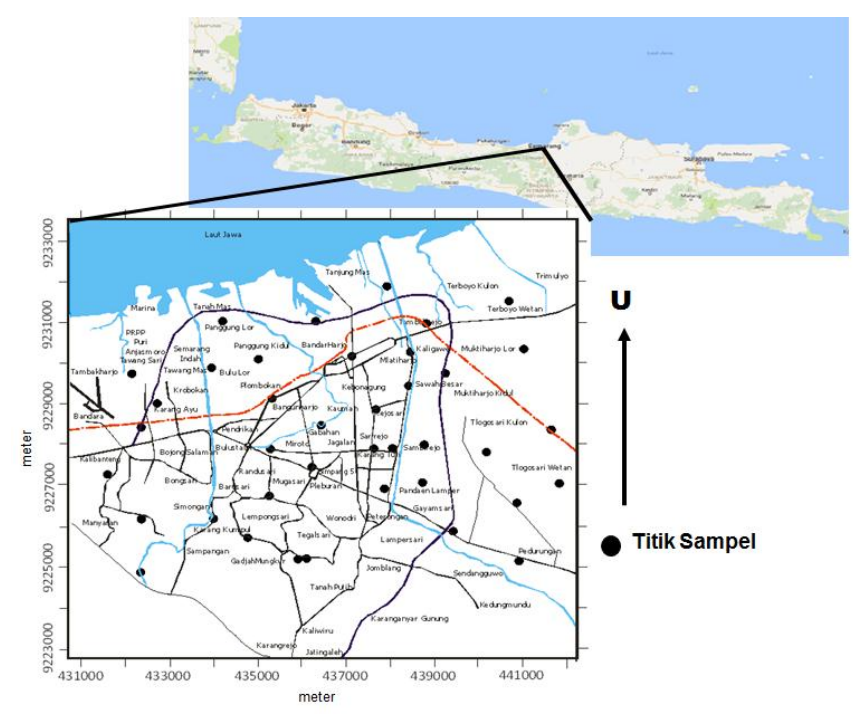

Gambar 1. Lokasi penelitian dan sebaran titik sampel kota Semarang

Figure 1. Location of the study and distribution of sample points Semarang

Koordinat titik sampel ditentukan dengan GPS (Global Positioning System) merk Garmin tipe 78s (Garmin, 2010) (Gambar 2) 


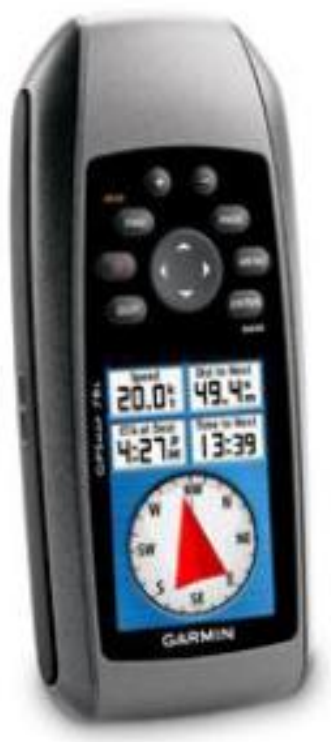

Gambar 2. Garmin 78s (Garmin, 2010)

Figure 2. Garmin 78 s (Garmin 2010)

Uji kualitas air tanah dilakukan dengan pengambilan sampel air tanah dilakukan dengan menggunakan alat multiparameter alat cek kualitas air (water quality checker) dengan merek TOA DKK WQC 24 (TOA DKK, 2004) (Gambar 3)

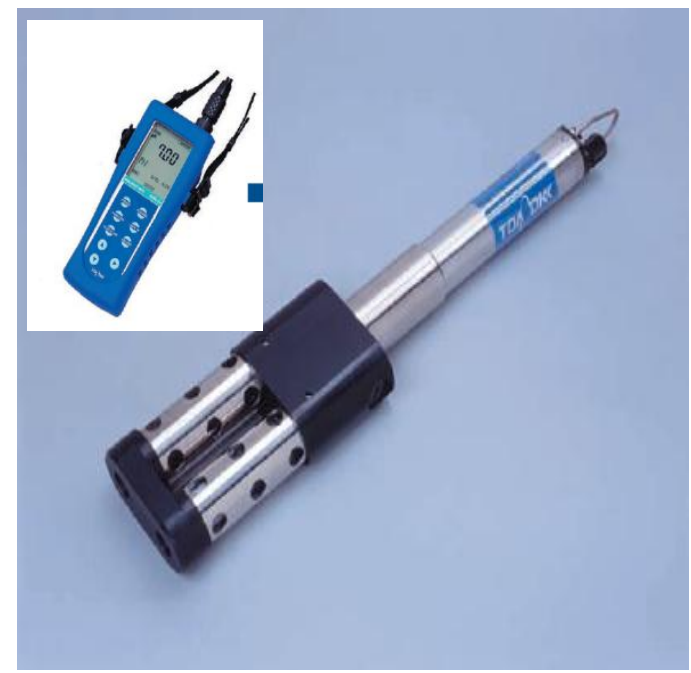

Gambar 3. Alat pengukur kualitas air multiparameter TOA DKK WQC-24 (TOA DKK, 2004)

Figure 3. Gauges multiparameter water quality TOA WQC-24 DKK (DKK TOA, 2004)

Pengukuran kualitas air tanah meliputipengukuran $\mathrm{pH}$, kandungan garam (salinitas), dan DHL (daya hantar listrik) dengan alat TOA DKK WQC-24.
$\mathrm{pH}$ adalah derajat keasaman yang digunakan untuk menyatakan tingkat keasaman atau kebasaan yang dimiliki oleh suatu larutan dan didefinisikan sebagai kologaritmaaktivitasion hidrogen $\left(\mathrm{H}^{+}\right)$yang terlarut. Koefisien aktivitas ion hidrogen tidak dapat diukur secara eksperimental, sehingga nilainya didasarkan pada perhitungan teoritis. Skala $\mathrm{pH}$ bukanlah skala absolut. Ia bersifat relatif terhadap sekumpulan larutan standar yang $\mathrm{pH}-n y a$ ditentukan berdasarkan persetujuan internasional. $\mathrm{pH}$ air menunjukkan aktivitas ion hidrogen dalam larutan tersebut dan dinyatakan sebagai konsentrasi ion hidrogen (dalam mol per liter) pada suhu tertentu, atau dapat ditulis :

$$
\mathrm{pH}=\log \left(\mathrm{H}^{+}\right)
$$

Derajat keasaman $(\mathrm{pH})$ air yang lebih kecil dari 6,5 atau $\mathrm{pH}$ asam meningkatkan korosifitas pada benda-bendalogam, menimbulkan rasa tidak enak dan dapat menyebabkan beberapa bahan kimia menjadi racun yang mengganggu kesehatan (Sutrisno, 2006). Pada umumnya perairan laut maupun pesisir memiliki $\mathrm{pH}$ relatif lebih stabil dan berada dalam kisaran yang sempit, biasanya berkisar antara 7,6 - 8,3 yang berarti bersifat basa atau disebut alkali (Brotowidjoyo et al., 1995).

Salinitas adalah kadar garam terlarut dalam air. Satuan salinitas adalah per mil (\%), yaitu jumlah berat total (gr) material padat seperti $\mathrm{NaCl}$ yang terkandung dalam 1000 gram air laut (Arief, 1984). Salinitas air tawar bernilai $<0,5 \%$, air payau 0,5-5\%, dan air asin 5-30 \%o (Disbang DKI Jakarta, 1997).DHL (daya hantar listrik) merupakangambaran numerik dari kemampuan air untuk meneruskan listrik. DHL air adalah suatu kebalikan tahanan dalam ohm yang diukur pada muka tanah yang

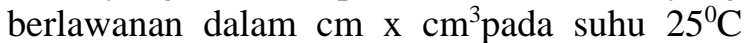
diukur dalamumhos. Jadi hantaran listrik adalah merupakan kebalikan dari tahanan, tetapi karena besarnya DHL ini sangat kecil maka biasanya dinyatakan dalam $\mu$ mhos yang besarnya sama dengan 10-6 mhos. (Arislan. 1989).dimana standart yang digunakan untuk klasifikasi air tanah dengan daya hantar listrik yakni kurang dari $900 \mu \mathrm{mhos} / \mathrm{cm}$ air tanah tawar (DHL rendah), 900-2000 $\mu$ mhos $/ \mathrm{cm}$ payau (DHL sedang), dan lebih besar dari 
$2000 \mu \mathrm{mhos} / \mathrm{cm}$ air asin (DHL tinggi) (Davis, 1996).

Teknik pembuatan peta zonasi sebaran intrusi air asin di kota Semanag dengan cara menggabungkan semua parameter yang di uji pada air tanah di daerah penelitian yang meliputi $\mathrm{pH}$, salinitas dan nilai daya hantar lisrik (DHL) sehingga bisa menghasilkan peta zonasi sebaran intrusi air asin di kota Semarang.

Air tanah merupakan sumber air yang terdapat di bawah permukaan tanah pada lajur/zona jenuh air (saturation zone) (Gambar 4). Sumber air tanah berasal dari air hujan dan air permukan yang meresap (infiltrate) mula-mula ke zona tak jenuh (aeration zone), kemudian meresap semakin mendalam hingga mencapai zona jenuh air dan akhirnya menjadi air tanah. Air tanah adalah salah satu fase dalam daur hidrologi, yakni suatu peristiwa yang selalu berulang dari urutan tahap yang dilalui air dari atmosfer ke bumi dan kembali ke atmosfer. Penguapan dari darat, laut atau air pedalaman selanjutnya terjadi pengembunan membentuk awan, pencurahan, pelonggokan dalam tanah atau badan air kemudian penguapan kembali (Kodoatie, 2003).

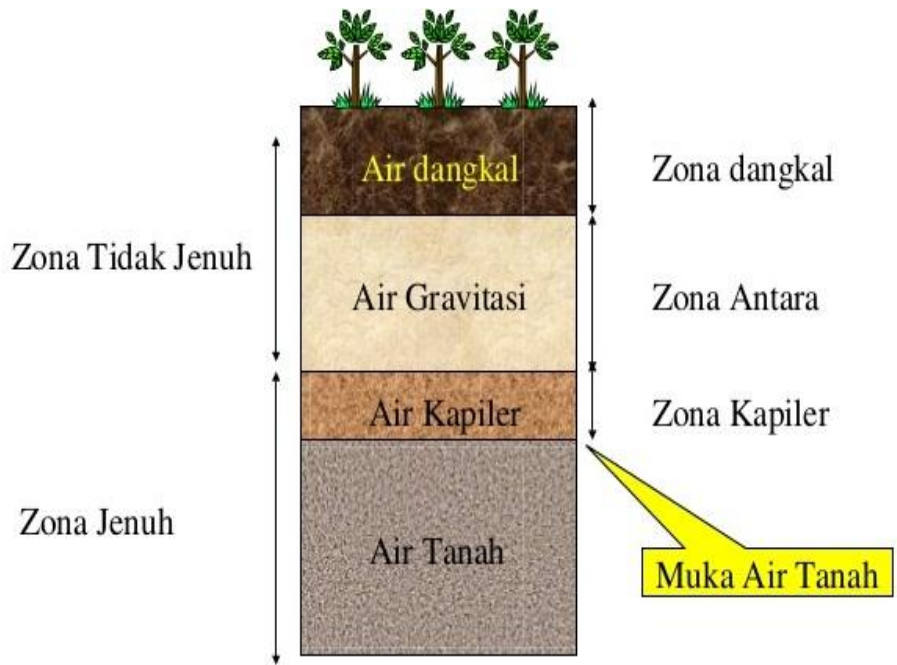

Batas dasar --> impermeabel

Gambar 4. Distribusi air bawah permukaan (Todd, 1980)

Figure 4. Distribution of subsurface water (Todd, 1980)

Akuifer adalah suatu lapisan formasi bawah permukaan tanah, atau kelompok formasi satuan geologi yang tidak kedap air (permeable) baik yang terkonsolidasi (misalnyalempung) maupun yang tidak terkonsolidasi (pasir)dengan kondisi jenuh air dan mempunyai suatubesaran konduktivitas hidraulik (K) sehingga dapatmembawa air (atau air dapat diambil) dalam jumlah(kuantitas) yang ekonomis (Kodoatie, 1996)

\section{HASIL DAN PEMBAHASAN}

Dari hasil penelitian yang telah dilakukan pada 40 titik sampel air tanah yang tersebar di kota Semarang (Gambar 1) diperoleh sebaran nilai $\mathrm{pH}$, Salinitas dan DHL (daya hantar listrik). Sebaran nilai $\mathrm{pH}$ di kota Semarang dilakukan pengukuran secara langsung (insitu) pada air tanah ditunjukkan oleh gambar 5 .

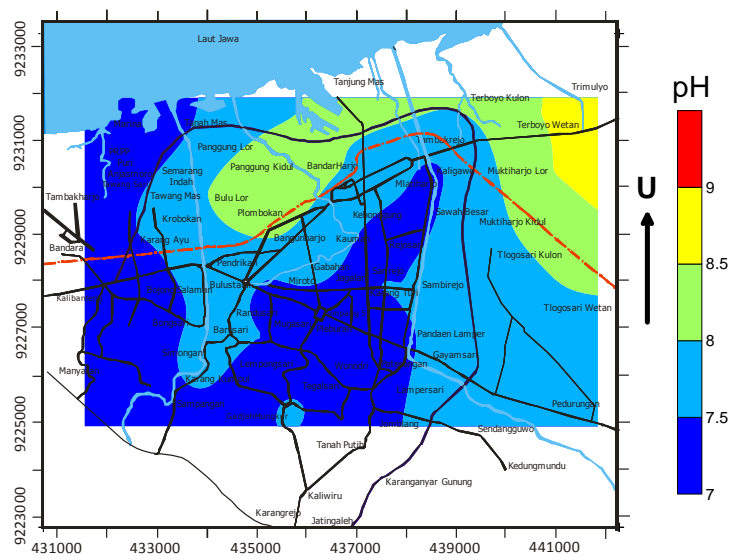

Gambar 5. Peta sebaran $\mathrm{pH}$ kota Semarang Figure 5. Distribution map of pH Semarang

Berdasarkan gambar 5 dapat dilihat bahwa $\mathrm{pH}$ sebagian besar kota Semarang sedikit di atas dari $\mathrm{pH}$ netral yaitu 7. Hal ini disebabkan karena sampel air tanah yang diukur telah mengandung air asin, karena air asin mengandung garam-garam mineral seperti $\mathrm{NaCl}$ dan mengandung ion-ion $\mathrm{Ca}^{2+}$ dan $\mathrm{Mg}^{2+}$ yang cukup besar. Ion-ion Calsium dan Magnesium akan membentuk garam-garam karbonat dan bikarbonat, yang selanjutnya campuran asam-asam karbonat tersebut dengan garam-garam membentuk suatu sistem penyangga (buffer) yang kuat. Keberadaan air asin di dalam akuifer air tanah mungkin berasal dari laut, sehingga $\mathrm{pH}$ air laut berada sedikit di atas netral yaitu pada batas $\mathrm{pH} 7,6-8,3$ yang besifat basa (Brotowidjoyo et al., 1995).Daerah yang memiliki nilai $\mathrm{pH}$ tinggi diatas 8 meliputi 
Tanah Mas, Panggung Kidul, Bandarharjo, Bulu Lor, Plobokan, Terboyo Kulon, Terboyo Wetan, Trimulyo,Muktiharjo Lor, dan Tlogosari Kulon.

Hasil pengukuran salinitas air tanah (Gambar 6), menunjukkan bahwa di beberapa tempat air tanahnya sudah terindikasi payau dengan nilai salinitas sebesar 0,5-5 \%o yang diantaranya Marina, Pusar rekreasi dan promosi pembangunan (PRPP), Puri Anjasmoro, Tambakharjo, Kalibanteng, Karang Ayu, Krobokan, Semarang Indah, Bangun Harjo, Tanah mas.Tanjung Mas, Tambakrejo, Bandarharjo, Kebonagung, Rejosari, Sarirejo, Tlogosari Kulon, Tlogosari Wetan, Muktiharjo Kulon, Sawah Besar, Muktiharjo Lor Terboyo Wetan, Terboyo Kulon, Pendurungan. Unsur senyawa garam yang ada di laut pada umumnya berupa $\mathrm{Na}, \mathrm{Cl}, \mathrm{NaCl}, \mathrm{MgSO} 4$, unsur senyawa garam ini dapat mencemari air tanah sehingga bisa berubah menjadi air payau (Hutabarat et al, 1984).Untuk wilayah tenggara kota Semarang terutama di Pendurungan salinitasnya bernilai tinggi diduga karena pelarutan mineral-mineral garam yang ada di dalam tanah masuk ke dalam air tanah.

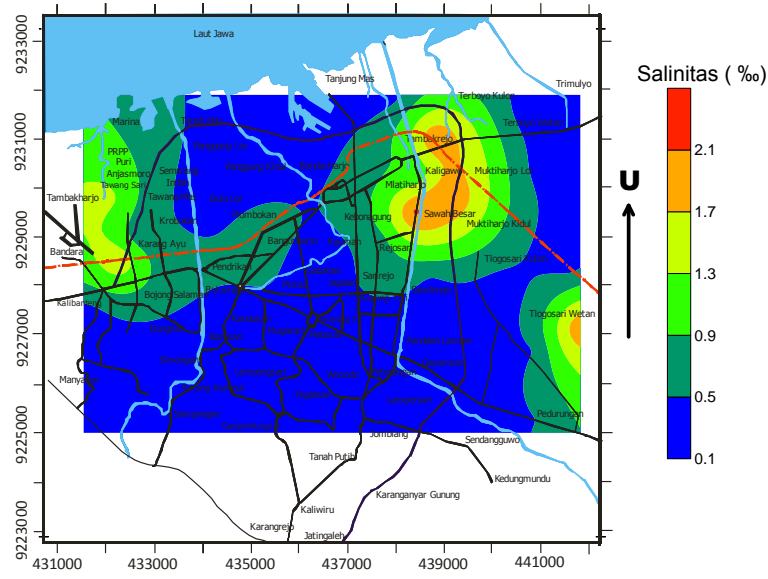

Gambar 6. Peta sebaran Salinitas kota Semarang Figure 6. Map of the distribution of salinity in Semarang

Konduktivitas atau daya hantar listrik (DHL) air bergantung pada jumlah ion-ion terlarut per volumenya dan mobilitas ion-ion tersebut, nilai daya hantar listrik (DHL) bertambah besar seiring dengan bertambahnya salinitas dari air tanah tersebut. Nilai daya hantar listrik (DHL) air tanah kota Semarang (Gambar 7) yang diperoleh dari hasil pengukuran langsung di sumur penduduk, sebagian besar wilayah yang diukurair tanahnya terindentifikasi sudah menjadi payau dengan nilai DHL antara 900$2000 \mu \mathrm{mhos} / \mathrm{cm}$ (Davis,1996) yang meliputi wilayah Tanah Mas, Panggung Lor, Panggung Kidul, Bandarharjo, Semarang indah, Tawang Mas, Bulu Lor, Plobokan, Krobokan, Karang Ayu, Bojong Salaman, Bulustalan, Pendrikan, Kauman,Gabahan, Jagalan, Miroto, Randusari, Mangunsari, Simpang Lima, Pleburan, Karang Turi, Sambirejo, Pandan Lemper. Nilai DHL tinggi lebih besar dari $2000 \mu \mathrm{mhos} / \mathrm{cm}$ yang diduga sebagai air asin yang telah mencemari air tanah meliputi dearah Semarang Utara yang meliputi Marina, PRPP, Puri Anjasmoro, Tawang Sari, Tambakharjo, Tanjung Mas, Terboyo Kulon, Terboyowetan, Tambakrejo, Kaligawe, Mlatiharjo, Sawahbesar, Kebon Agung, Rejosari,Sarirejo, Muktiharjo Lor, Muktiharjo Kidul yang diduga penyebabnya adalah intrusi air laut. Nilai DHL tinggi juga terdapat di daerah Semarang Selatan yang meliputi daerah Tlogosari Wetan dan Pendurungan, dugaan penyebabn nilai DHL tinggi di daerah Semarang Selatan adalah adanya pelarutan mineral-mineral tanah yang mengandung garam yang masuk kedalam akuifer air tanah dan mencemari air tanah menjadi asin.

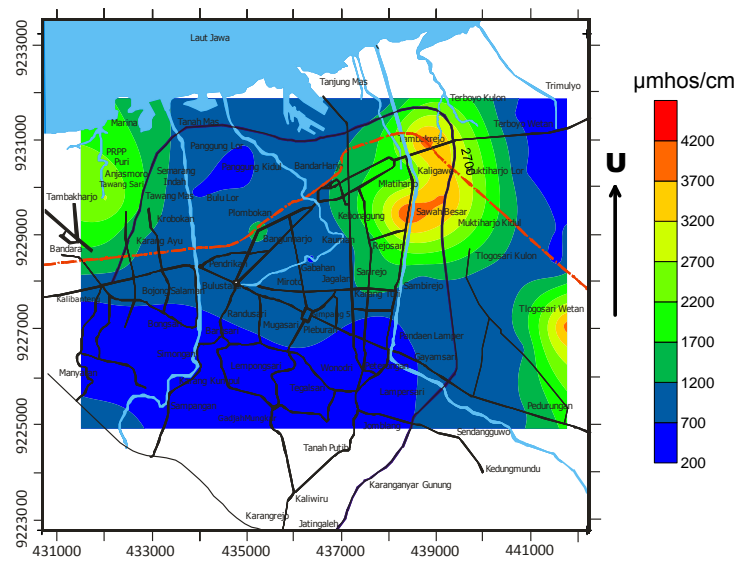

Gambar 7. Peta sebaran DHL kota Semarang Figure 7. Distribution map DHL Semarang

Berdasarkan ketiga peta sebaran $\mathrm{pH}$, salinitas dan DHL di kota Semarang maka dibuat peta zonasi untuk mengetahui sebaran intrusi air asin di kota Semarang (Gambar 8). 


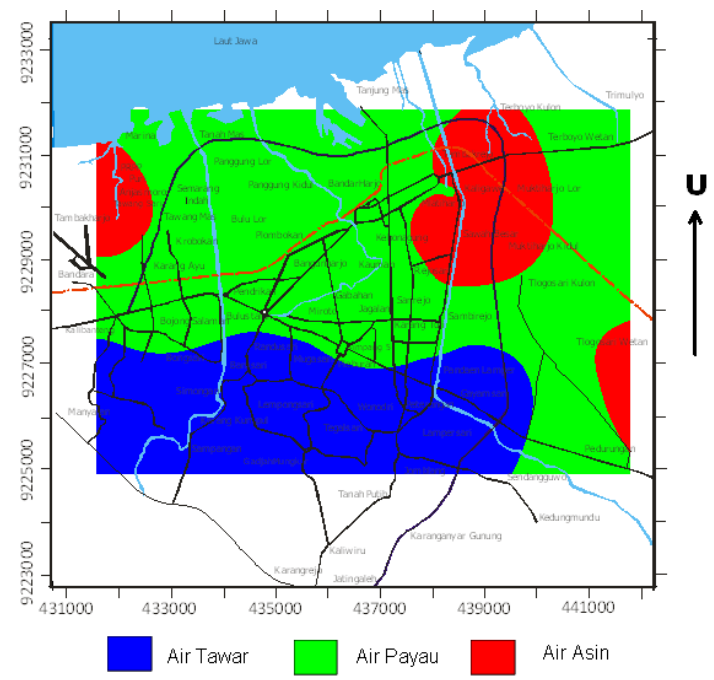

Gambar 8. Peta zonasi air asin kota Semarang

Figure 8. The zoning map brine Semarang

Hasil peta zonasi air asin di kota Semarang memperlihatkan bahwa sebagian besar wilayah kota Semarang air tanahnya sudah tercemar dengan air asin sehingga dibeberapa tempat air tanahnya sudah menjadi payau. Dampak dari berubahnya fungsi air tanah menjadi payau akan muncul secara berkala dan untuk jangka waktu yang lama jika didiamkan saja tanpa ada upaya mencegahnya. Hal tersebut tentu saja akan menimbulkan kerugian yang sangat besar bagi masyarakat. Penggunaan air payau untuk dikonsumsi maunusia maupun untuk kegiatan kebutuhan lain seperti mandi, dapat mengganggu kesehatan, karena air payau mengandung $\mathrm{NaCl}$ (Natrium Chloride) yang tinggi dan dapat mengganggu metabolisme yang terjadi di dalam tubuh manusiajika dikonsumsi dapat menyebabkan seseorang terkena penyakit perut seperti diare, sedangkan bila digunakan untuk mandi, dapat memicu munculnya penyakit kulit, seperti gatal-gatal (Harahap, 2000).

Intrusi air asin yang terjadi di kawasan pesisir kota Semarang merupakan masuknya air laut kedalam akuifer air tanah di kawasan pesisir hal ini merupakan bentuk degradasi sumberdaya air terutama oleh aktivitas manusia pada kawasan pesisir kota Semarang. Hal ini perlu diperhatikan sehingga segala bentuk aktivitas manusia pada daerah tersebut perlu dibatasi dan dikendalikan sebagai wujud kepedulian terhadap lingkungan.

\section{KESIMPULAN DAN SARAN}

Hasil uji kualitas fisik air tanah menunjukkan nilai $\mathrm{pH}$ bersifat basa dan dapat diidentifikasi sebagai air payau. Nilai salinitas yang terukur pada umumnya masuk dalam katagori air payau. Nilai daya hantar listrik (DHL) air tanah diatas $900 \mu \mathrm{mhos} / \mathrm{cm}$ yang terjadi di sebagian kota Semarang mengakibatkan berubahnya fungsi air tanah menjadi air payau. Berdasarkan peta zonasi, sebagian besar wilayah kota Semarang fungsi air tanahnya sudah berubah menjadi air payau dan hanya beberapa lokasi di wilayah Semarang selatan yang masih terdapat zona air tawarnya.

\section{DAFTAR PUSTAKA}

Arief, D.,(1984). Pengukuran salinitas air laut dan pernannya dalam ilmu kelautan. Oseana Volume IX Nomor 1.

Arislan, A., (1989). Studi Hidrologi Waduk Cengklik Kabupaten Boyolali. Skripsi.Fakultas Geografi. Universitas Gadjah Mada, Yogyakarta.

Brotowijoyo, M. D., Dj. Tribawono., E. Mulbyantoro., (1995). Pengantar Lingkungan Perairan dan Budidaya Air, Liberty Yogyakarta.

Davis, S.N. dan Wiest, R.J.M., (1996). Hydrogeology, New York. Jhon Willey \& Sons. Inc.

[Dep Kimpraswil] Departemen Permukiman dan Prasarana Wilayah.,(2003).Standar Penggunaan Air Bersih, Ditjen Cipta Karya. Departemen Pemukiman dan Prasarana Wilayah. Jakarta.

Disbang DKI Jakarta - Sapta Daya Karyatama., (1997).Observasi Intrusi Air Asin/Laut di Wilayah DKI Jakarta. Laporan Akhir.

GARMIN, 2010., GPSMAP 78 Series Manual http://gpscentrs.lv/instrukcijas/GPSMAP _78_OM_EN.pdf. [diunduh06september-2016].

Harahap, M., (2000).Ilmu Penyakit Kulit,Penerbit Hipokrates, Jakarta.

Hutabarat, $S$ dan Stewart M. E., (1984).Pengantar Oseanografi. Jakarta, Penerbit Universitas Indonesia Press

Kodoatie, R. J., (1996). Pengantar Hidrogeologi. ANDI offset. Yogyakarta

Kodoatie, R, J.,(2003). Manajemen dan Rekayasa Infrastruktur.Pustaka Pelajar. Yogyakarta. 
Marsudi, (2000). Prediksi Laju Amblesan Tanah di Dataran Alluvial Semarang Propinsi Jawa Tengah.Disertasi Program Pascasarjana ITB.

Susanto A., (2010). Strategi Kebijakan Pemanfaatan Air Tanah Sebagai Sumber Air Bersih di kota Semarang yang Berkelanjutan. Tesis Sekolah pAsca Sarjana IPB. Bogor

Sutrisno, T., (2006). Teknologi penyediaan air bersih. Rineka Cipta. Jakarta.

TOA DKK, (2004).Instruction Manual Hand Held Water Quality Meter WQC-24. Tokyo. Japan.

Todd, D.K., (1980). Groundwawater Hydrology, $2^{\text {nd }}$ Jhon Wiley, New York, USA

Winanti, T., (2008). Konservasi Air Tanah. Unesa University Press. Surabaya.

http://dispendukcapil.semarangkota.go.id/statist ik/jumlah-penduduk-kotasemarang/2015-10-11 (diunduh 16 September 2016).

http://www.kompasiana.com/tholo/10-kotaterbesar-di-indonesiavalid_552047a9813311f77319f72b(diun duh 16 September 2016). 
